\title{
ULTRASOUND WAVES FOR ASSESSING THE TECHNOLOGICAL PROPERTIES OF Pinus caribaea VAR hondurensis AND Eucalyptus grandis WOOD
}

\author{
Patrícia Gomes Ribeiro ${ }^{1 \star}$, Joaquim Carlos Gonçalez ${ }^{2}$, Raquel Gonçalves ${ }^{3}$, \\ Ricardo Faustino Teles ${ }^{4}$, Frederico de Souza ${ }^{4}$
}

\begin{abstract}
The forest sector plays an important role in the economy and, in these times of sustainability, industries need to save natural resources and leverage them as best as possible in order to achieve excellence in product quality and win the consumer market. The use of advanced technologies and improvement in pre-existing techniques is the most efficient way to understand the raw material, and improve the quality of products manufactured and their rational use. The use of nondestructive technologies has proven effective in characterizing and assessing wood quality. This work aims to predict certain physical and mechanical properties of Pinus caribaea and Eucalyptus grandis, using ultrasound. The research was conducted at the University of Brasilia (UNB), in conjunction with the Forest Products Laboratory (LPF/SFB) and the State University of Campinas (UNICAMP/SP). The results permit us to state that certain physical-mechanical properties of these species can be predicted with ultrasound. The property best estimated is density, followed by modulus of elasticity and modulus of rupture.
\end{abstract}

Keywords: Wood properties, nondestructive technique, ultrasound.

\section{INTRODUCTION}

Nondestructive evaluation using acoustic waves has been used to estimate the properties of standing trees, logs, boards and veneer (Shimoyama 2005); the strength properties of panels (Matos 1997, Matos et al. 2000) and to assess poles, timber bridges and other structures, emphasizing direct application at the location of assembly (Ross 1999).

The ultrasonic technique stands out as an important tool, with the potential to improve the quality and competitiveness of wood. As such, one must understand the phenomenon of ultrasonic wave propagation within the material, and establish relationships between the involved variables (Oliveira 2001).

According Ross and Pellerin (1985), the application and measurement of stress waves consists of positioning two transducers on the material to be measured, and emitting a wave that travels through the material. Wood quality can be directly correlated with velocity, permitting the determination of minor discontinuities and the condition of the wood sample.

\footnotetext{
${ }^{1}$ Forest Engineer, M.Sc., Ph.D. Student in Forest Science, Faculty of Technology, University of Brasília, Brasília - DF, 70904-970, Brazi

${ }^{2}$ Adjunct Professor, Dr. Department of Forest Engineering, Faculty of Technology, University of Brasília, Brasília - DF, 70904-970, Brazil, goncalez@unb.com.br.

${ }^{3}$ Civil Engineer, Professor, Dr., Department of Rural Buildings, UNICAMP, Campinas - SP, Brazil, raquel@feagri.unicamp.br.

${ }^{4}$ Forest Engineer, M.Sc., Professors, Federal Institute for Education, Science and Technology of Brasília - IFB, Campus Samambaia -

Brasília-DF, ricardo.teles@ifb.edu.br, frederico.souza@ifb.edu.br.

^Corresponding author: ribeiropg@unb.br

Received: 09.03. 2012 Accepted: 29.102012
} 
Morales (2006) reported the factors that most influence the propagation of ultrasonic waves in solid wood are moisture content, the $d / \lambda$ ratio (where $d$ is the distance traveled by the wave, which may be equivalent to the length of the piece, and $\lambda$ is the wavelength), wave frequency and density. Bucur and Böhnke (1994) stated that the propagation of ultrasonic waves is also affected by the geometric characteristics of the wood. Several studies (Pelizan 2004, Stangerlin et al. 2009) have demonstrated the relationship between these parameters and the mechanical elastic constant of wood and $\mathrm{C}_{\mathrm{LL}}$, the dynamic constant in the longitudinal direction (parallel to the fibers). The equation for the propagation of a wave along the longitudinal axis of the wood is $C_{L L}=V^{2} / \rho$.

Gonçalez (2001) cites the simplified equation of wave propagation in the principal axes of wood, $\mathrm{V}^{2}=\mathrm{Ei} / \rho$ (where: $\mathrm{V}$ is the velocity of propagation of the wave; $\mathrm{E}_{\mathrm{i}}$ is the modulus of elasticity (MOE) of wood along an axis (longitudinal, radial or tangential) and $\rho$ is the density). In total, there are nine equations. When the Poisson coefficient is not taken into account, we have $V^{2}=E_{L} / \rho$, where $E_{L}$ is the Young's modulus in the longitudinal axis and, according to Sandoz (1990), as close as to MOE as found with standard techniques.

Bucur (2006), defines the velocity of propagation as the distance traveled by the ultrasonic wave per unit time, and is directly related to wavelength and frequency.

Gonçalez et al. (2001) estimated the elastic constants of four species of Amazon wood, and observed that the ultrasonic velocity in the wood was greater in the longitudinal direction than the radial, which is greater than the tangential.

Ballarin and Nogueira (2005) determined MOE of juvenile and mature Pinus taeda wood from the dynamic constant $\mathrm{C}_{\mathrm{LL}}$, and the results showed good sensitivity of the ultrasonic method $\left(\mathrm{R}^{2} \approx 0.90\right)$.

Prediction of wood properties, such as modulus of rupture (MOR) and density is poor according to Daniels and Clark III (2006); the best property provided by the method is MOE, since it is directly related to the velocity of wave propagation. With dynamic constants, it is possible to establish relationships with MOE obtained by destructive testing (Gonçalves and Silva 2003).

This study aims to determine the elastic constant in the longitudinal direction and the velocity of wave propagation, using ultrasound to predict certain physical and mechanical properties, such as the density and MOE for Pinus caribaea and Eucalyptus grandis.

\section{MATERIALS AND METHOD}

This research was conducted at the University of Brasilia, in conjunction with the Forest Products Laboratory - LPF/SFB (Forest Service), and the State University of Campinas (UNICAMP) - SP.

In this study, we have used two commercial tree species, Eucalyptus grandis and Pinus caribaea var. hondurensis, both 18 years old, from the municipality of Catalão - Goiás. The samples were obtained from three $200 \mathrm{~mm}$ x $40 \mathrm{~mm}$ x $2500 \mathrm{~mm}$ (width x thickness x length) boards of each species, which were tested for basic density and shrinkage (COPANT 461/72 and COPANT 462/71) and flexure flexure in midpoint loading, as standard COPANT 30:1-006/72, performed with a Universal Testing Machine, model DL30000, maximum capacity $300 \mathrm{kN}$, mark EMIC. Testing was done at the LPF/SFB Physics and Engineering Laboratory.

Ultrasonic tests were conducted at UNICAMP, using 12 samples of each species. The samples used in the ultrasonic measurements, $20 \mathrm{~mm} \times 20 \mathrm{~mm} \times 300 \mathrm{~mm}$ ( $w \times t \times l$; radial $\mathrm{x}$ tangential $\mathrm{x}$ longitudinal $)$, were also used in the conventional bending tests. The ultrasonic equipment used was a Panasonics EPOCH 
4, with a frequency of $1 \mathrm{MHz}$, established by the transducers provided. The samples had a longitudinal direction and two parallel planar faces (transverse).

For each sample, measurements were made of propagation time $(\mu \mathrm{s})$ and the velocities were calculated. Using the velocity, we calculated $\mathrm{C}_{\mathrm{LL}}$ and dynamic modulus of elasticity $\left(\mathrm{MOE}_{\mathrm{d}}\right)$ in the longitudinal direction (parallel to the fibers), according to Equation 1.

$$
M O E=V^{2} \times \rho_{12 \%} \times \frac{1}{g}
$$

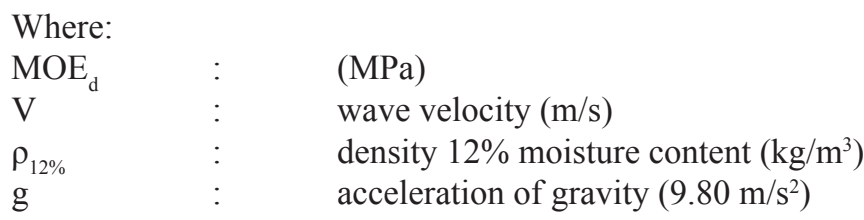

The results obtained in conventional tests were analyzed for mean, minimum, maximum, and standard deviation. The results were subjected to analysis of variance (ANOVA), at $1 \%$ and $5 \%$ significance levels. The results from conventional tests were correlated with those of nondestructive testing. Pearson correlations at $1 \%$ and $5 \%$. The Tukey test was used at $5 \%$ significance level when necessary. To estimate the values of physical and mechanical properties were performed regression analyzes.

\section{RESULTS AND DISCUSSION}

The values of density and volumetric, tangential and radial shrinkage of Pinus caribaea and Eucalyptus grandis are shown in table 1.

Table 1. Average values for density and shrinkage of Pinus caribaea and Eucalyptus grandis.

\begin{tabular}{lccccc}
\hline \multirow{2}{*}{ Species } & $\begin{array}{c}\text { Density } \\
\left(\mathbf{k g} / \mathbf{m}^{3}\right)\end{array}$ & Volumetric & Tangential & Radial & Ratio (T/R) \\
\cline { 3 - 6 } & $\mathbf{4 6 0}$ & $\mathbf{1 2 . 4 7}$ & $\mathbf{8 . 2 1}$ & $\mathbf{4 . 9 1}$ & $\mathbf{1 . 8 3}$ \\
Pinus caribaea & $(0.03)(0.07)$ & $(1.28)(0.10)$ & $(0.73)(0.09)$ & $(0.50)(0.10)$ & $(0.45)(0.24)$ \\
& $(420)(510)$ & $(10.33)(15.20)$ & $(7.06)(9.36)$ & $(4.09)(5.82)$ & $(1.25)(2.55)$ \\
Eucalyptus & $\mathbf{5 6 0}$ & $\mathbf{1 3 . 7 6}$ & $\mathbf{7 . 6 5}$ & $\mathbf{6 . 2 5}$ & $\mathbf{1 . 2 2}$ \\
grandis & $(0.02)(0.03)$ & $(0.86)(0.06)$ & $(0.69)(0.09)$ & $(0.68)(0.11)$ & $(0.22)(0.18)$ \\
& $(540)(590)$ & $(12.69)(15.38)$ & $(6.64)(8.85)$ & $(5.10)(7.27)$ & $(0.86)(1.57)$ \\
\hline
\end{tabular}

Values in parentheses are, respectively, standard deviation, coefficient of variation (\%), minimum and maximum values.

Pinus caribaea is considered to be of low density $\left(460 \mathrm{~kg} / \mathrm{m}^{3}\right)$, according to Melo et al. (1990) and the value obtained is consistent with studies by Bendtsen (1978) and Gonçalez et al. (2008). The mean values of tangential, radial and volumetric shrinkage were $8.21,4.91$, and $12.47 \%$, respectively. These values are expected for the genus Pinus and, among these data, the radial shrinkage was closest to that found in the literature (Gonçalez et al. 2008). The T/R ratio can be considered normal (1.83), although this is greater than that described in the literature for this genus (Costa 1996, Gonçalez et al. 2008), implying that this wood could present major problems when used in the industry, and must be machined, or it will check and warp. 
Eucalyptus grandis is considered by Melo et al. (1990), as medium density $\left(560 \mathrm{~kg} / \mathrm{m}^{3}\right)$ and the values in table 1 are consistent with studies by Costa (1996) and Stangerlin et al. (2008). Hillis (2000) states that the density limits of younger wood in the genus Eucalyptus are between 400 and $800 \mathrm{~kg} / \mathrm{m}^{3}$. Our Eucalyptus grandis had shrinkage values lower than those found by Gonçalez et al. (2006), and a low $\mathrm{T} / \mathrm{R}$ ratio.

Table 2 shows data from static bending tests (destructive) and ultrasonic tests (nondestructive).

Table 2. Values in the table should have static bending rather than ultrasonic tests.

\begin{tabular}{lcccc}
\hline \multirow{2}{*}{ Species } & \multicolumn{2}{c}{ Ultrasound } & \multicolumn{2}{c}{ Static Bending Tests } \\
& $\mathbf{V}_{\mathbf{L L}}$ & $\mathbf{C}_{\mathbf{L L}}$ & MOE (MPa) & MOR (MPa) \\
\hline \multirow{2}{*}{ Pinus caribaea } & $\mathbf{5 5 5 5}$ & $\mathbf{1 8 6 2 2}$ & $\mathbf{1 0 0 8 4}$ & $\mathbf{9 1}$ \\
& $(257.35)(0.05)$ & $(2054.71)(0.11)$ & $(840.14)(0.08)$ & $(458.51)(0.04)$ \\
Eucalyptus grandis & $\mathbf{5 0 5 7}$ & $\mathbf{1 8 0 2 0}$ & $\mathbf{1 0 5 4 6}$ & $\mathbf{1 0 4}$ \\
& $(289.60)(0.06)$ & $(1240.17)(0.07)$ & $(8.56)(0.09)$ & $(5.27)(0.05)$ \\
\hline
\end{tabular}

Values in parentheses are, respectively, standard deviation and coefficient of variation (\%).

The average MOE for Pinus caribaea was $10084 \mathrm{MPa}$ and the upper and lower limits were 11526 $\mathrm{MPa}$ and $8985 \mathrm{MPa}$, respectively. For MOR of Pinus, the average value was $91 \mathrm{MPa}$ and the upper and lower limits were $110 \mathrm{MPa}$ and $79 \mathrm{MPa}$, respectively. The MOR and MOE for Pinus caribaea was close to that found by Santini (2000) and Gonçalez et al. (2008).

The average MOE of Eucalyptus grandis was $10546 \mathrm{MPa}$ and the upper and lower limits were 11675 $\mathrm{MPa}$ and $10033 \mathrm{MPa}$, respectively. Silva (2002), in studying the same species at 20 and 10 years old found MOE of $12673 \mathrm{MPa}$ and $7986 \mathrm{MPa}$, respectively. For MOR of Eucalyptus, the mean value was $104 \mathrm{MPa}$ and the upper and lower limits were $113 \mathrm{MPa}$ and $94 \mathrm{MPa}$, respectively.

The mean values of ultrasonic wave velocity is similar to the literature (Zerbini 2008, Gonçalez et al. 2001), with values of $4000-6000 \mathrm{~m} / \mathrm{s}$.

The use of ultrasonic velocity to predict properties confirms that with is advocated by Daniels and Clark III (2006). Namely, that the best predictive results, among the properties studied for density and modulus of elasticity.

From the data obtained, we were able to establish a general relationship of density $12 \%$ moisture content to longitudinal velocity, as shown in figure 1, with the following:

$$
\rho_{12 \%}=0.174 V_{L L}-440
$$




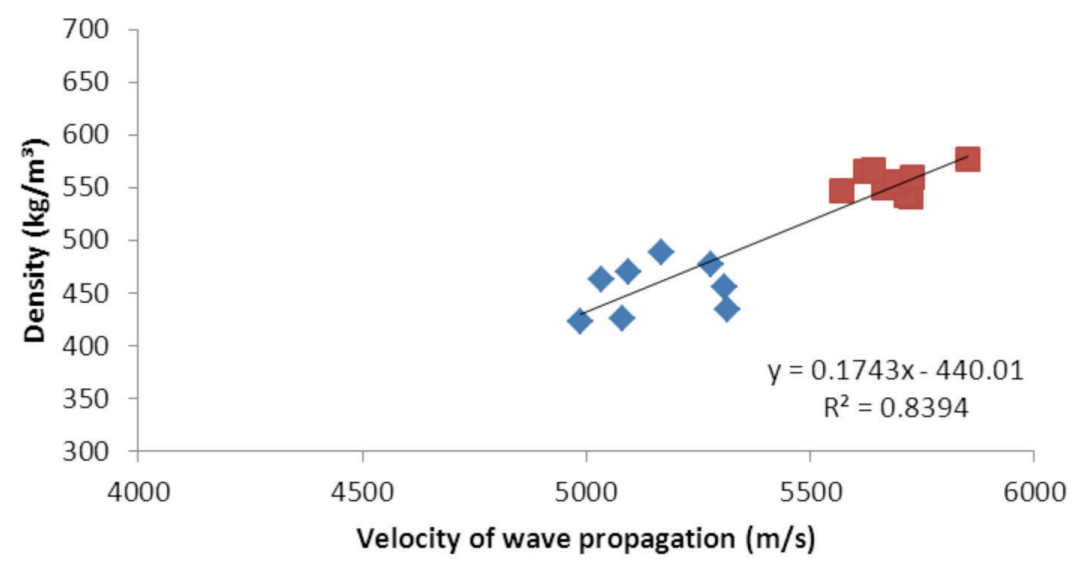

- Pinus Eucalyptus

Figure 1. Scatter diagram and regression line between density at $12 \%$ moisture content and velocity wave propagation

Similar results were obtained by Oliveira and Sales (2005), for Pinus caribea, P. elliottii, Eucalyptus grandis, E. citriodora, Hymenaea sp and Goupia glabra, confirming the use of wave velocity to predict density. For the regressions between MOE and MOR with wave velocity, coefficients of determination $\left(\mathrm{R}^{2}\right)$ of 0.38 and 0.24 were obtained, respectively.

In comparing the dynamic spring constant and MOE, the former is about 1.78 times greater than the latter. Ouis (2002) states that this is because of the viscoelastic nature of wood, which is more prominent in static bending, and which has been long compared with ultrasonic tests.

The consequence is that the dynamic elastic constant obtained in ultrasonic testing is generally greater than MOE in bending.

Figure 2 shows the scatter plot and regression line between the data for MOE in static bending and MOE measured by ultrasonically for Pinus and Eucalyptus. In the data analysis, the extreme points (outliers) were ignored. Variance analysis was used to verify the quality of the fitted model as shown in table 3.

Table 3. ANOVA for the data of static and dynamic MOE.

\begin{tabular}{cccccc}
\hline Source of variation & $G l$ & $S Q$ & $M Q$ & $F$ & Significant $F$ \\
\hline Regression & 1 & $1,23 \mathrm{e}+08$ & $1,23 \mathrm{e}+08$ & 73,72 & $4,96 \mathrm{e}-10$ \\
Residue & 34 & 56804838 & 1670731 & & \\
Total & 35 & $1,8 \mathrm{e}+08$ & & & \\
\hline
\end{tabular}




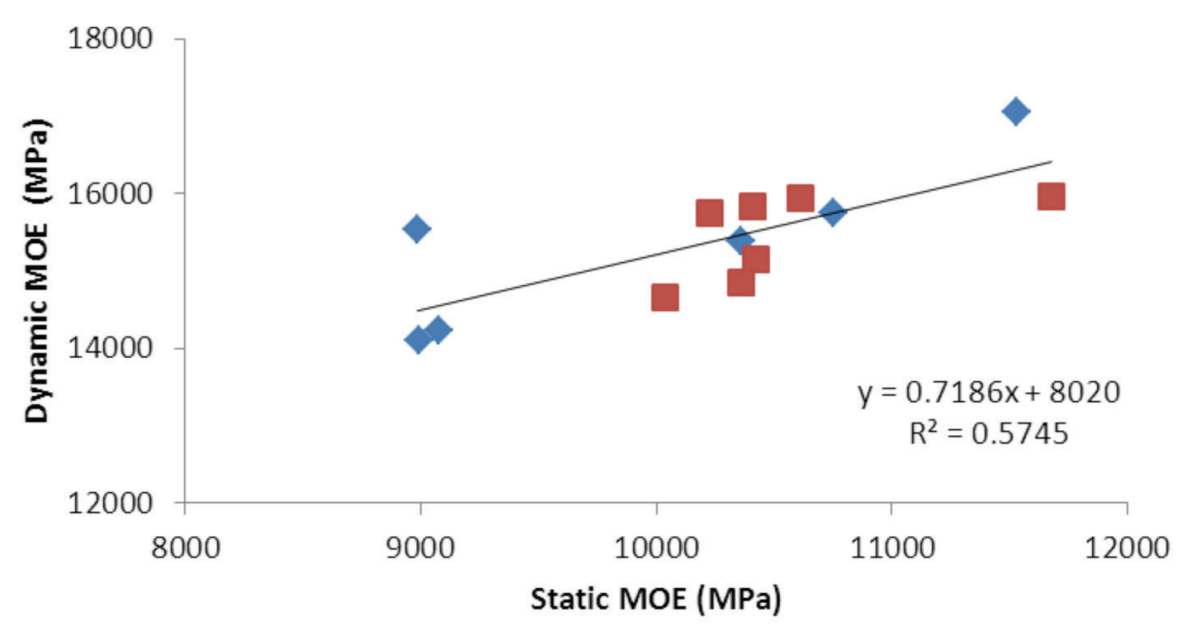

Figure 2. Scatter diagram and regression line between static and dynamic MOE.

The regression line between dynamic and static MOE had an $\mathrm{R}^{2}$ of 0.57 , which is not overly high, but significant. This result demonstrates the greater value of the ultrasonic technique for MOE. However, it did not permit separation of MOE of Pinus and Eucalyptus, since the property values are similar. The property coefficients are consistent with those typically found in the literature (Carreira et al. 2006, Sales et al. 2004). 
Pinus caribaea

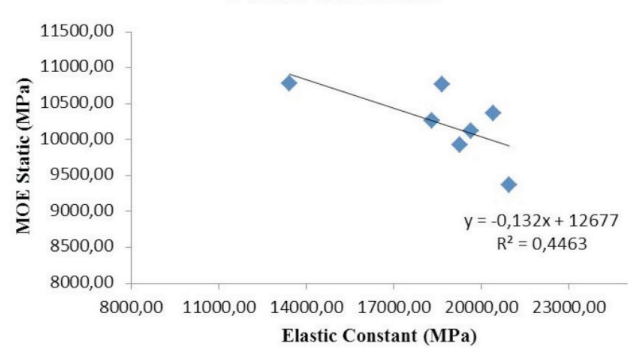

(i)

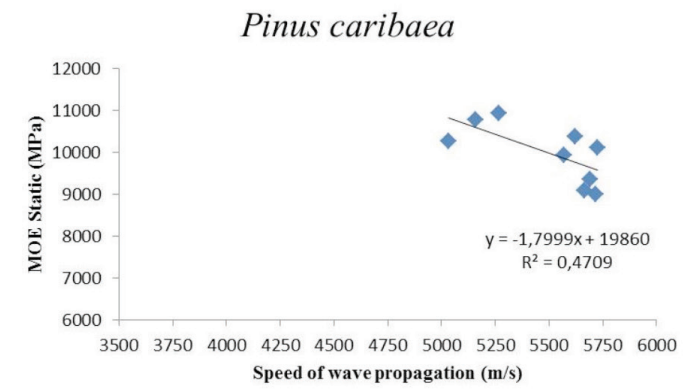

(ii)

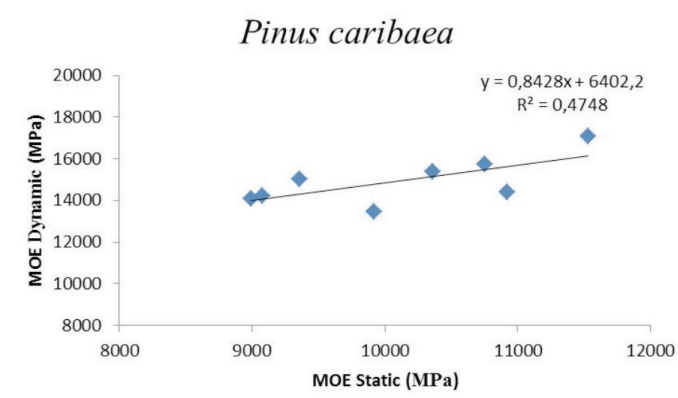

Eucalyptus grandis
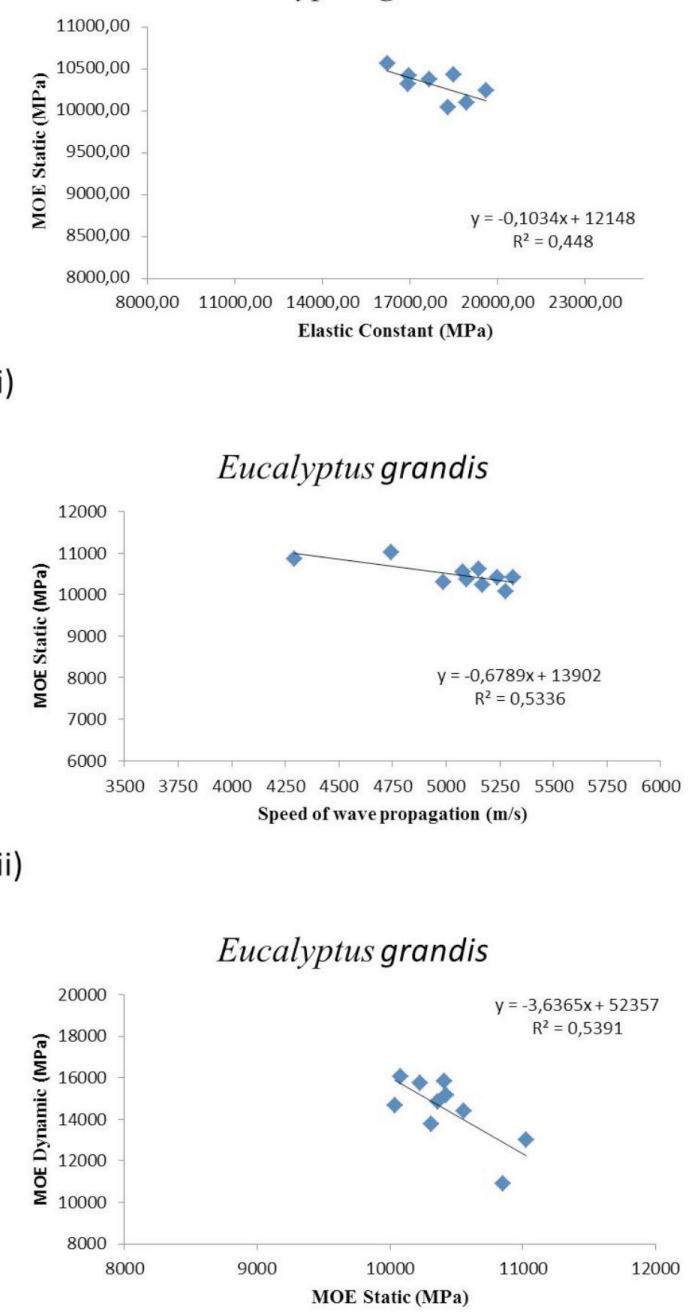

(iii)

Figure 3. Scatter plots and regression lines between static MOE and their correlation with the elastic constant (i), the speed of wave propagation (ii) and dynamic modulus of elasticity (iii), for Pinus and Eucalyptus woods.

Figure 3 shows the regression lines between static MOEs and (i) the elastic constant (ii), the propagation velocity and (iii) the from 0.45 to 0.47 for Pinus and 0.45 and 0.54 for Eucalyptus. These results are similar to those obtained by Daniels and Clark III (2006) in a study of Pinus quality quantification and prediction. Moreover, Carreira et al. (2006) obtained a higher coefficient of determination for the regression equation for dynamic and static modulus of elasticity, 0.90 for Pinus $\mathrm{sp}$. The values found for E. grandis are similar to those reported by Bartholomeu and Gonçalves (2007), comparing beams from E. citriodora and E. grandis, of $120 \times 60 \times 2500 \mathrm{~mm}$ in dimension, under saturated conditions (above $30 \%$ moisture content) and air dried (12\% moisture content). For E. grandis, correlation coefficients of 0.59 and $0.43\left(\mathrm{R}^{2}=0.35\right.$ and 0.18$)$ were found, respectively. Moreover, Sales et al. (2004), when evaluating Eucalyptus poles, found correlations between static and dynamic MOE with an $\mathrm{R}^{2}$ of 0.61 . 
For both species, a good correlation was observed between dynamic and static MOE.

The ultrasonic wave velocity can be used to predict wood density and MOE; for both Pinus and Eucalyptus, the correlations were significant - at 1\% and 5\%, respectively.

Among the advantages of using ultrasound is the possibility of performing evaluation and classification of sampled wood pieces in an industrial production line, or for evaluation of the entire line, that is, the natural pieces.

\section{CONCLUSIONS}

Ultrasonic wave technique may be considered as alternatives to destructive testing in characterizing Pinus caribaea var. hondurensis and Eucalyptus grandis.

It is an important tool to infer the nondestructive (dynamic) MOE of wood. Although the values of elastic modulus obtained by destructive and nondestructive methods are different because of the viscoelastic nature of wood, the ultrasonic method is more rapid and offers an opportunity for much greater sampling. The technique also can easily be employed by production personnel.

\section{REFERENCES}

Ballarin, A. W.; Nogueira, M. 2005. Determinação do módulo de elasticidade da madeira juvenil e adulta de Pinus taeda por ultrassom. Revista Eng. Agrícola 25(1):19-28.

Bartholomeu, A.;Gonçalves, R. 2007. Predição do Módulo de Elasticidade à Flexão em vigas de Eucalipto saturadas e secas ao ar utilizando a velocidade longitudinal de ultrassom. In: IV Conferencia Panamericana de END. Buenos Aires.

Bendtsen, B. 1978. Properties of wood from improved and intensively managed trees. Forest Products Journal 28(10): 61-72.

Bucur, V.2006. Acoustics of wood. Springer-Verlag, Berlin. 393p.

Bucur, V.; Böhnke, I. 1994. Factors affecting ultrasonic measurements in solid wood.Ultrasonics 32(5):385-390.

Cangiani, S. M. P. 1993. Qualidade da madeira de Pinus na Duraflora. IPEF (Série Técnica) 9(27): 30-34.

Carreira, M. R; Cheung, A. B.; F. Oliveira, G. R.; Dias. A. A.; Calil Júnior. C.; Sales, A.; Candian, M. 2006. Classificação de peças estruturais de Pinus sp por ultrassom. In: $17^{\circ} \mathrm{CBECIMat}$ Congresso Brasileiro de Engenharia e Ciência dos Materiais. Foz do Iguaçu, Paraná, Brasil: 8316-8328.

Costa, E. M. 1996. A madeira de Eucalyptus na indústria moveleira. In: Seminário sobre processamento e utilização da madeira de reflorestamento. ABPM/ SBS, p. 75- 89. Curitiba: Paraná.

Daniels, R. F.; Clark III, A. 2006. Quantifying and predicting wood quality of Loblolly and Slash Pine under intensive forest management. USDA Forest Service and Silvi Scan, CSIRO.Final Technical Report. 
Gonçalez, J. C.; Breda, L. de C. S.; Barros, J. F. M.; Macedo, D. G.; Janin, G.; Costa, A. F. da; Vale, A. T. do. 2006. Características tecnológicas das madeiras de Eucalyptus grandis W.Hill ex Maiden E. Eucalyptus cloeziana F. Muell visando ao seu aproveitamento na indústria moveleira. Revista Ciência Florestal 16 (3):329-341.

Gonçalez, J. C.; Vale, A. T. do.;Costa, A. F. da. 2001. Estimativas das constantes elásticas da madeira por meio de ondas ultrassonoras (ultrassom). Revista Cerne 7(2): 81-92.

Gonçalez, J. C.; Zerbini, N. J.;Gouveia, F. N.; Macedo, D. G.; D’ambros, J. 2008. Características tecnológicas da madeira de Pinus caribaea var.hondurensis visando sua utilização em ambientes interiores. In: XI Encontro Brasileiro em Madeira e Estruturas de Madeira. Londrina. Paraná, Brasil.

Gonçalves, R.; Silva, S. A. M. 2003. Correlações entre módulo de elasticidade e constante dinâmica em chapas MDF. In: III Pan-American Conference for Nondestructive Testing. PAN NDT. Rio de Janeiro. Brasil.

Hillis, W. E. 2000.Wood quality and growing to meet market requirements. In: The Future of Eucalypts for Wood Products. Launceston, Tasmania. Launceston: IUFRO: 256-264.

Matos, J. L. M. 1997. Estudos sobre a produção de painéis estruturais de lâminas paralelas de Pinus taeda L. Curitiba. Tese (Doutorado). Setor de Ciências Agrárias. Universidade Federal do Paraná.

Matos, J. L. M.; Keinert JR., S.; Rosa, G. M. 2000.Uso de métodos de emissão acústica para determinação não destrutiva de propriedades de painéis compensados de madeira. In: Encontro brasileiro em madeiras e em estruturas de madeira. São Carlos, São Paulo: UFSC: 131-137.

Melo, J. E. de; Coradin, V. T. R.; Mendes, J. C. 1990. Classes de densidade para madeiras da Amazônia brasileira. In: Anais. Congresso Florestal Brasileiro 3: 695-699, Campos do Jordão, São Paulo, Brasil.

Morales, E. A. M. 2006. Técnicas de propagação de ondas na estimativa de propriedades mecânicas de painéis OSB. Tese (Doutorado). Interunidades Ciência e Engenharia de Materiais, da Universidade de São Paulo, São Paulo, Brasil.

Oliveira, F. G. R. 2001. Estudo de propriedades mecânicas de dicotiledôneas por meio de ensaio não-destrutivo utilizando equipamento de ultrassom. Dissertação (Mestrado). Universidade de São Paulo, São Paulo, Brasil.

Oliveira, F. G.R; Sales, A. 2005. Efeito da densidade e do teor de umidade na velocidade ultrasônica da madeira. Minerva 2(1): 25-31.

Ouis, D. 2002. Dispersion of wood as a consequence of its viscoelasticity. In: International Symposium on Nondestructive Testing of Wood. Berkeley: University of California.

Pelizan, T. R.2004. Estudo de propriedades mecânicas de peças roliças de Eucalipto citriodora utilizando a técnica de ultrassom. Dissertação (Mestrado). São Carlos: Universidade de São Paulo USP, $71 \mathrm{p}$.

Ross, R. J. 1999. Inspection of timber bridges using stress wave timing nondestructive evaluation tools - A guide for use and interpretation. Forest Products Laboratory, Madison, General Technical report. 
Ross, R. J.; Pellerin, R. F. 1985. NDE of wood-based composites with longitudinal stress waves. Forest Products Journal 38(5): 39- 45.

Sales, A.; Pelizan, T. R.; Oliveira, F. G. R.; Candian, M.; Lucchette, F. F.; Salgon, J. F.; Miller, K.P. 2000. Avaliação de propriedades mecânicas de peças roliças de Eucalyptus por meio de ultrassom. In: IX Encontro Brasileiro em Madeiras e em Estruturas de Madeira- IBRAMEM/LaMEM.. Cuiabá, Mato Grosso, Brasil.

Sandoz, J. L. 1990. Triage et fiabilité des bois de construction. Validité de la méthodeultrasson. Thèse (docteur en Sciences Techniques) - EPFL, Lausane, Suiça.

Santini, E. J.; Haslein, C. R.; Gatto, D. 2000. Análise comparativa das propriedades físicas e mecânicas de três coníferas de floresta plantada. Ciência Florestal 10(1): 85-93.

Shimoyama, V. R. S. 2005. Estimativas de propriedades da madeira de Pinus taeda através do método não destrutivo emissão de ondas de tensão, visando à geração de produtos de alto valor agregado. Tese (Doutorado) - Universidade Federal do Paraná, Brasil.

Silva, J. C. 2002. Caracterização da madeira de Eucalyptus grandis Hill ex. Maiden, de diferentes idades, visando a sua utilização na indústria moveleira. Tese (Doutorado). Curitiba: UFPR. Brasil.

Stangerlin, D. M.; Calegari, L.; Santini, E. J. O.; Domingues, J. M. X. O.; Gatto, D. A. O.; Melo, R. R. 2008. Determinação do módulo de elasticidade em madeiras por meio de métodos destrutivo e não destrutivo. Revista Brasileira de Ciências Agrárias 3 (2):145-150.

Stangerlin, D. M.; Gatto, D. A.; Melo, R. R.; Calegari, L.; Vivian, M. A.; Castelo, P. A. R.; Beltrame, R. 2010. Uso do ultrassom para estimativas das propriedades mecânicas da madeira de Peltophorumdubium. Ciência da Madeira1(2): 44-53.

Zerbini, N. J. 2008. Madeiras tropicais com potencial comercial da região do rio Xingu (Pará, Brasil): propriedades tecnológicas e cadeia produtiva.Tese (Doutorado). Brasília: Universidade de Brasília, Brasil. 